\title{
Contagious bank failures in a free banking system
}

\section{Citation}

Aghion, Philippe, Patrick Bolton, and Mathias Dewatripont. 2000. "Contagious Bank Failures in a Free Banking System.” European Economic Review 44 (4-6) (May): 713-718.

\section{Published Version}

doi:10.1016/S0014-2921(00)00058-1

\section{Permanent link}

http://nrs.harvard.edu/urn-3:HUL.InstRepos:12490629

\section{Terms of Use}

This article was downloaded from Harvard University's DASH repository, and is made available under the terms and conditions applicable to Other Posted Material, as set forth at http:// nrs.harvard.edu/urn-3:HUL.InstRepos:dash.current.terms-of-use\#LAA

\section{Share Your Story}

The Harvard community has made this article openly available.

Please share how this access benefits you. Submit a story.

\section{Accessibility}




\title{
Contagious Bank Failures in a Free Banking system
}

\author{
by \\ Philippe Aghion \\ University College London, CEPR and EBRD \\ Patrick Bolton \\ Princeton University and CEPR \\ and \\ Mathias Dewatripont \\ ECARE, Universite Libre de Bruxelles and CEPR
}

August 1999 


\section{Introduction}

An increasingly influential view on banking regulation holds that:

1. the proliferation of bank failures over the past two decades is caused to a large extent by "safety-net" regulations put in place during the great depression to avert banking panics, and that

2. the only way to regain financial stability is to remove these protections and let the banking system operate with minimal regulatory intervention:

3. Protection against systemic shocks can be provided more efficiently through private institutional arrangements such as clearing houses (see e.g. Calomiris (1999)).

In this short paper we shall examine more closely the last point by considering equilibria in an unregulated banking sector, which may be vulnerable to contagious bank runs. We base our analysis on a model developed in Aghion, Bolton and Dewatripont (1999).

\section{Our Model}

The model is variation of Diamond and Dybvig (1983) and Postlewaite and Vives (1987) with multiple banks. It has four periods and it allows for $N \geq 2$ banks, each with the same mass of depositors. At date $t=0$, each depositor deposits $I=1$ in their local bank. This deposit (plus

interest if any) can be withdrawn at any subsequent date $t \in\{1,2,3\}$. As 
in Diamond and Rajan (1998) a fraction of depositors wants to withdraw an amount $I=1$ from the bank at each date $t \in\{1,2,3\}$ to invest it in a better project (offering a private gross return of $B>1$ ). A depositor with a better investment opportunity at date $t$ is referred to as a type- $t$ depositor. At date $t=0$ depositors do not know their type. They only learn whether they are of type $t$ at date $t \in\{1,2,3\}$ (this is strictly true only for types $t=1,2$, since type $t=3$ is bound to learn her type by elimination at date $t=2$ ).

Banks offer deposit contracts $\left\{d_{1}, d_{2}, d_{3}\right\}$, where $d_{t}$ is the total amount that can be withdrawn at date $t$, for every dollar invested at date 0 (provided there have been no previous withdrawals). In equilibrium depositors choose to withdraw everything they have in a single period so that it is not necessary to consider other withdrawal patterns. For $B$ sufficiently large, it is optimal for a bank to commit to repay $d_{1} \geq 1$ and $d_{2} \geq 1$. Each bank invests deposits obtained at date $t=0$ in a partially liquid project which yields cash-flow $r_{t}$ at date $t=1,2,3$ for every dollar invested at date $t=0$. The bank can only bring forward future cash flow at a cost of $(1-\gamma)$ per dollar (with $\gamma<1$ ). Cash-flow may be random, so that a bank may not always have the cash available to meet the demand for withdrawals. In that case it may borrow cash from other banks. Should it be unable to raise enough cash to pay back all its deposit obligations then (as is standard) it is assumed that depositors are paid back on a first come first served basis.

The cash-flow structure takes the following simple form. Cash-flows 
are independently and identically distributed, with:

$$
\left(r_{1}, r_{2}, r_{3}\right)=\left\{\begin{array}{lll}
R_{1}-\Delta, R_{2}-\Delta, 0 & \text { with prob. } & (1-q) \\
\left(R_{1}, R_{2}, R_{3}\right) & \text { with prob. } & q p \\
\left(R_{1}-\Delta, R_{2}-\Delta, R_{3}+2 \Delta\right) & \text { with prob. } & q(1-p)
\end{array}\right.
$$

where, $R_{t}>1$ for all $t, R_{t}-\Delta<\frac{1}{2}$ for $t=1,2$ and $R_{1}+R_{2}<3$.

This allows for an insolvency state (when $r_{3}=0$ ) as well as a state with a liquidity shortage (when $r_{t}=R_{t}-\Delta$ for $t=1,2$ and $r_{3}=$ $\left.R_{3}+2 \Delta\right)$.

To simplify matters it is assumed that the insolvency state can only occur with positive probability if the bank does not invest prudently. That is, insolvency is due to moral hazard in lending, which occurs when banks are protected by a public safety net.

The timing of moves and events is as follows: at date $t=0$ banks post their deposit contracts and depositors invest their wealth in their local bank. At date $t=1$ type 1 depositors learn their type and withdraw their funds. If a bank is unable to meet all withdrawals it fails, an event which is public information. Depositors withdraw at the latest when they need cash (in period $t$ when they are of type $t$ ), but they can also choose to withdraw earlier (for example if they fear that the bank may be insolvent).

As is well known early withdrawal can lead to a self-fulfilling rational panic. Thus, it may be rational for type 2 and 3 depositors to all run to their banks at date 1 . We shall ignore these equilibria and concentrate instead on contagious panics triggered by an individual bank failure. Such panics can arise at date $t=2$ when type- 3 depositors run on their bank following the failure of some other bank at date 1 . 


\section{Equilibrium under a Clearing house arrangement}

In this section we consider an idealization of a banking system based around a clearing house arrangement. Under the best possible scenario such a system would be able to eliminate any risk of insolvency through effective peer monitoring by member banks of the clearing house. With no insolvent members the clearing house can provide maximum co-insurance against idiosyncratic liquidity shortages through interbank lending, as long as there is no aggregate liquidity shortage.

We shall suppose that the cash-flow realization of each bank is private information, so that no one in the system is able to assess global liquidity needs at date $t=1$. In addition we preclude fully contingent interbank loan offers mainly because they are not realistic. If such offers were allowed then banks with excess cash at date $t=1$ could perfectly condition their lending decision on realized global liquidity supply. By doing so, they might be able to shield themselves against contagious bank runs as we explain below. However, this is obviously unrealistic. Therefore, we shall consider a somewhat crude but more realistic model of the interbank loan market. We shall suppose that the clearing house quotes an unconditional interbank lending rate $i$ and whenever demand does not match supply the short side of the market is rationed on a random equiprobable basis. The rate $i$ is set at a level such that banks with surplus liquidity are just indifferent between lending on the interbank market or not. This is the efficient unconditional interbank rate.

If $B$ is sufficiently large the optimal contract offered by each member 
bank is such that $d_{t}=1$ for $t=1,2$ and $d_{3}=\frac{1+\rho}{1-Q}$, where $Q$ is the probability of losing one's deposit following the failure of the bank at any date $t=1,2,3$ and $\rho>0$ is an interest payment on the deposit account that is just high enough to induce depositors to put their savings in the bank. This contract is optimal because it guarantees that depositors can take out enough money to be able to invest in the more profitable opportunity whenever it arises (as long as the bank does not fail), and because subject to this constraint the bank is left with maximal residual liquidity at date $t=1,2$.

Suppose that $N_{1}$ banks in the system are subject to a liquidity shock. Then the remaining $\left(N-N_{1}\right)$ banks have enough cash to lend them to overcome the liquidity shortage of all $N_{1}$ banks at date $t=1$ if and only if:

$$
N_{1}\left(R_{1}-\Delta\right)+\left(N-N_{1}\right) R_{1} \geq N
$$

and at date $t=2$ if and only if

$$
N R_{2}-N_{1} \Delta+\left(N R_{1}-N_{1} \Delta-N\right) \geq N
$$

Note that in equilibrium all banks with a liquidity shortage only borrow an amount $\left(1+\Delta-R_{t}\right)$ in each period $t=1,2$. That is, it is not optimal for a bank with a liquidity shortage to borrow upfront at date $t=1$ enough to cover all its future liquidity needs. This would involve excessively high interbank interest payments.

When conditions ( 1 and 2 ) hold no bank fails at date $t=1$ and type 2 and 3 depositors are assured that there is enough cash in the system to meet all their withdrawals (provided, of course, that type 3 depositors 
do not panic and withdraw all their funds at date $t=2$ ).

Suppose that conditions (1 and 2) fail, then at least one illiquid bank must bring forward future cash-flow to meet its date $t=1$ demand for withdrawals. If it is very costly to liquidate part of its long term investment to meet the demand for date $t=1$ withdrawals (as it is likely to be when there is a global liquidity shortage) then the bank may not be able to generate sufficient cash and may go bankrupt. This is the case if:

$$
1+\Delta-R_{1}>\gamma\left(R_{2}+R_{3}+\Delta\right)
$$

We shall proceed assuming that this condition holds, so that at least one bank will fail when

$$
N_{1}\left(R_{1}-\Delta\right)+\left(N-N_{1}\right) R_{1}<N
$$

Then, having observed at least one bank failure at date $t=1$, depositors in other banks can infer that repayments to type-1 depositors have absorbed all the period 1 cash-flow of the remaining banking system.

This information can trigger a contagious bank run in an otherwise solvent banking system. To see this, note that the failure of a bank at date $t=1$ implies that at least $\bar{N}$ of the remaining banks have had a liquidity shock (where $\bar{N}$ is given by the smallest integer greater than $(N-1) \frac{R_{1}-1}{\Delta}$ when only one bank fails), so that the amount of cash available per bank to meet date $t=2$ withdrawals is at most $R_{2}-\bar{N} \Delta<1$ (for $R_{2}$ sufficiently small).

Therefore, to meet these withdrawals the remaining banks must bring 
forward cash-flow from the future at an average cost of

$$
(1-\gamma)\left(1+\bar{N} \Delta-R_{2}\right)
$$

If this cost is too high it becomes a dominant strategy for type 3 depositors to withdraw early and run to the bank at date $t=2$. More precisely, if

$$
R_{3}+2 \Delta-\left(1-R_{2}+\Delta\right)-(1-\gamma)\left(1+\bar{N} \Delta-R_{2}\right)<1
$$

then it is a dominant strategy for all type 3 depositors to run on the remaining solvent banks following the observation of the failure of at least one member bank at date $t=1$.

We have thus illustrated how the most efficient clearing house arrangement imaginable may be vulnerable to a contagious run on the whole system. This is admittedly a somewhat extreme scenario. A slightly more realistic story might be to have contagious run on part of the system only. Nevertheless this simple example dramatically illustrates our main point that a clearing house system is prone to contagious bank runs precisely when it is extremely efficient at weeding out imprudent banks. By doing so it removes any ambiguity on how to interpret the failure of one of its' members. Such a failure signals an aggregate liquidity shortage (and thus facilitates a run on the entire system) all the more clearly the less likely any member bank is to become insolvent through mismanagement.

Efficient free banking systems thus appear to be potentially vulnerable to systemic risks. These risks can be eliminated by extending a 
public safety net over the entire banking sector. However, such a protection is bound to introduce inefficiencies in the form of moral hazard in bank lending, unless the central bank is able to discriminate between insolvent and illiquid banks and only bails out the latter. An intermediate solution might be to adopt a free banking system and to regulate the extent to which private clearing houses can exclude inefficient banks. As we point out in the next section, a less efficient free banking system, where banks may be prone to some moral hazard in lending may be less vulnerable to contagious runs.

\section{Moral hazard versus systemic risk}

Suppose now that all $N$ banks are less tightly monitored and engage in some imprudent lending. As a result any of these banks can now be insolvent with probability $(1-q)>0$. The optimal contract offered by each member bank is then such that $d_{t}=1$ for $t=1,2$ and $d_{3}=\frac{1+\rho}{1-\widehat{Q}}$ when $B$ is sufficiently large (where $\widehat{Q}>Q$ since any insolvent bank fails at date $t=1)$.

Now consider the following heuristic argument. The respective probabilities of the events that a single bank is insolvent at date $t=1$ or that a single bank fails due to a global liquidity shortage are $(1-q) q^{(N-1)}$ and approximately $\pi=\left(\frac{N}{N}\right) q^{N} p^{\bar{N}}(1-p)^{(N-\bar{N})}$. Clearly, for $q$ small enough the ratio $\frac{\pi}{(1-q) q^{(N-1)}}$ converges to zero. Therefore, for $q$ small enough depositors essentially assume that the bank failure was due to mismanagement rather than to a global liquidity shortage, so that they have no reason to run on the other banks. This reasoning extends to 
events where more than one bank is insolvent, except when the number of failing banks is so large that again a global liquidity crunch is the most likely source of the multiple failures.

\section{Concluding Remarks}

The main point of this paper is to illustrate that a free banking system may not be immune to contagious bank runs. Moreover, the more efficient such a system is at reducing the potential insolvency of individual banks the more it exposes itself to contagious runs should there be a global liquidity shortage. In other words, the more efficient the system is at reducing the likelihood of an individual bank failure the bigger the amplification of a systemic shock through contagious bank runs.

Clear implications for bank regulation cannot be drawn from these observations alone. A free banking system may dominate one with a public safety net if it reduces substantially the extent of moral hazard in lending. However, conditional on adopting a clearing house system it may be desirable to allow for sufficient risk taking by banks to ensure that the failure of an individual bank is not perceived by depositors as an unambiguous signal of a global liquidity crunch.

\section{References}

Calomiris, C. (1999) "Building an incentive compatible safety net", Journal of Banking and Finance, (forthcoming)

Aghion, P., P. Bolton, and M. Dewatripont (1999) "Contagious bank Failures", mimeo

Diamond, D. and P. Dybvig (1983) "Bank runs, deposit insurance, and liquidity", Journal of Political Economy, 91(3):401-19. 
Diamond, D. and R. Rajan (1998) "Liquidity Risk, liquidity creation and financial fragility: A theory of banking", mimeo, Graduate School of Business, Chicago.

Postlewaite, A. and X. Vives (1987) "Bank runs as an equilibrium phenomenon" Journal of Political Economy 95 (3):485-91. 